\title{
CONCEPT OF PRODUCT COMPETITIVENESS MANAGEMENT SYSTEM AND PRINCIPAL SCIENTIFIC APPROACHES TO ITS UNDERSTANDING
}

\author{
*Oksana Senyshyn"1, Oleksandr Kundytskyj², Marta Zlydnyk ${ }^{3}$ \\ ${ }^{1}$ Doctor of Economic Science, Professor, Ivan Franko National University of Lviv. Address: Krupyarska \\ St., 9, 79014, Lviv, Ukraine.Tel. +3809696718 47.E-mail Okssenyshyn@gmail.com \\ ${ }^{2}$ Doctor of Economic Science, Professor, Ivan Franko National University of Lviv. Address: Ivasyuka St., \\ 10, 79017, Lviv, Ukraine.Tel. +38067 73323 94.E-mailskund@ukr.net \\ ${ }^{3}$ Postgraduated student, Lviv University of Trade and Economics. Address: Sygnivka St., 5, 79040, Lviv, \\ Ukraine.Tel.+3806874164 41.E-mail: lts_marta@ukr.net
}

Received 1401 2020, Accepted 28052020

\begin{abstract}
This article presents the concept of product competitiveness, product competitiveness management, product competitiveness management system and outlines basic scientific approaches to its understanding. It is considered by the author from the standpoint of the systemic approach to management and is applied to the product, manufacturer, who can be an individual, enterprise, industry, region or a country in general. The objective of the scientific study is determination of the product competitiveness management system; generalization of scientific approaches to understanding the concept of competitiveness management. For implementation in the scientific article the purpose and tasks used a set of methods of scientific knowledge: the comparative method, system analysis method and methods of grouping and generalization - all helped to single out the principal approaches to the product competitiveness management. Theoretical and practical value of the research is systematization and characterization of the existing approaches, their combination for the product competitiveness management, and definition of the new approach to product competitiveness management based on the concept of "food safety".
\end{abstract}

Keywords: food safety, competitiveness assessment, management, systems.

JEL Codes: D41; M21.

\section{Introduction}

Until present time the conceptual and terminological problems of competitiveness and competitiveness management system have not been resolved completely. The absence of commonly accepted clear terms and their definitions leads to misunderstanding and errors in scientific interpretation of the phenomena under study.

Diversity of interpretation of the terms pertaining to the theoretical problems of competitiveness and competitiveness management system demonstrates the situation of disarray of the conceptual construct in this sphere of knowledge. It is characterized both, by the variety of definitions, and by their inadequacy, which complicates the study of economic problems of competition and product competitiveness.

The general questions of the agenda of competitive advantages, product competitiveness, product competitiveness management system are dealt with in some scientific works of Balabanova (2008; 2014), Chaudhary (2016), Granabetter (2016), Hubenko (2003), Ivanov (2010), Klepanchuk (2019), Kolkova (2018), Kotlyk (2007; 2012), Kundytskyj (2019), Lepeyko (2012), Markova (2010), Oleksenko (2007), Osovska (1993), Petrovych (2012), Porter (1992; 1993), Senyshyn (2014; 2019), Tarnavska (2008; 2010), Fatkhudinov (2001; 2009) and others.

Copyright (C) 2020. Published by Vytautas Magnus University. This is an open access article distributed under the terms of the Creative Commons Attribution Non-Commercial 4.0 (CC BY-NC 4.0) license, which permits unrestricted use, distribution, and reproduction in any medium provided the original author and source are credited. The material cannot be used for commercial purposes. 


\section{Oksana Senyshyn, Oleksandr Kundytskyj, Marta Zlydnyk \\ Concept of Product Competitiveness Management System and Principal Scientific Approaches to its Understanding}

Famous scientists-economists Osovska and Osovskyy reasonably point out that competitiveness of an industry is determined by its having technical, economic and organizational conditions for the creation, production and sales (with the costs not above the international costs) of high quality products, that satisfy the requirements of specific consumer groups (Osovska, 1993).

Competitiveness of an industry implies the presence of competitive advantages over similar industries abroad that can be expressed in the presence of a rational industry structure; groups of highly competitive companies-leaders that bring other enterprises of the industry up to their level; well-established research and development, progressive engineering and technological facilities, developed industry infrastructure, flexible system of scientific-technical, manufacturing, logisticaltechnical and commercial collaboration both, within the industry and with other industries in the country and abroad, an effective system of product distribution.

Thus, it is reasonable to conclude that, according to modern theoretical and methodological interpretation competitiveness of an industry is formed and determined under the effect of certain conditions that have an impact on activities of the economic entities, whose totality forms the industry.

The known scientists Yu, Ivanov, Kyzym (2010) understand competitiveness of the country, as the ability of national manufacturers to sell their products, the ability to increase, or at least retain, parts of the markets that are sufficient to expand and improve production, raise the living standards, keep up a strong and efficient state.

Porter $(1992 ; 1993)$ defines a country's competitiveness as the place it holds in the world economy. Thus, the level of competitiveness of a country is ensured by the level of competitiveness of individual enterprises of that country, and the country succeeds when the conditions contribute to the implementation of the best strategy by enterprises of any industry or its segment. Some particularities of the country facilitate or, on the contrary, complicate implementation of a strategy.

The lowest level in a multi-level hierarchical model of competitiveness is competitiveness of a commodity or products that demonstrates its/their ability to respond best to the customers' demands compared to similar products presented in the market. Analyzing the concepts of the competitiveness of a commodity or products, we demonstrate the fact that a wide range of scientists-economists (Fatkhutdinov, 2009; Oleksenko, 2007; Osovska, 1993; Porter, 1993) argue that competitiveness of a commodity (goods, products) is a complex of its consumer and cost characteristics that satisfy demands of the consumer better than similar products of the competitors.

Another group of scientists (Dishe, 2006; Kryveshko, 2012; Petrovych, 2012) define competitiveness of products as the ability to sell them successfully in a saturated market, as the ability of a commodity to be sold profitably and ensure a profit for the producer. That is, such definition of the product competitiveness is based on the relationship of competitiveness with a complex of consumer and value characteristics of the commodity that will make it superior among many competitors in satisfying demands of the consumer and, therefore, superiority in the sales policy.

Of great importance in the study of theoretical and methodological principles of product competitiveness management is the issue of diversity of approaches to this concept. Fathutdinov and Osovska $(1996 ; 2009)$ examine a range of approaches to competitiveness management: systemic; logical; reproductive-evolutionary; innovative; complex; global; integrative; virtual; standardized; marketing; exclusive; functional; process; structural; situational (variational); normative; optimization; top-down (administrative); behavioral; business.

The objective of the scientific study is determination of the concepts of products competitiveness, product competitiveness management, product competitiveness management system; generalization of scientific approaches to understanding the concept of competitiveness management. For the detailed analysis of scientific approaches to the product competitiveness management it is deemed expedient to identify the concept «product competitiveness management system» of the enterprise. 


\section{Proposed methodology}

To achieve the objective and accomplish the task we used the following set of scientific knowledge methods in this article:

- the comparative method - applied to compare the variety of interpretations of the product competitiveness;

- system analysis method - permitted to consider competitiveness from the standpoint of the systemic approach to management owing to which competitiveness of the product, manufacturer, region or country has been determined in general;

- methods of grouping and generalization - all helped to single out the principal approaches to the product competitiveness management.

\section{Result analysis}

We shall note that the concept of competitiveness in economic science is viewed from the standpoint of the systematic approach to management and applied depending on the product (commodity, service), manufacturer, that can be an individual, enterprise, industry, region or $a$ country in general. The multilevel model of competitiveness is shown in Fig. 1.

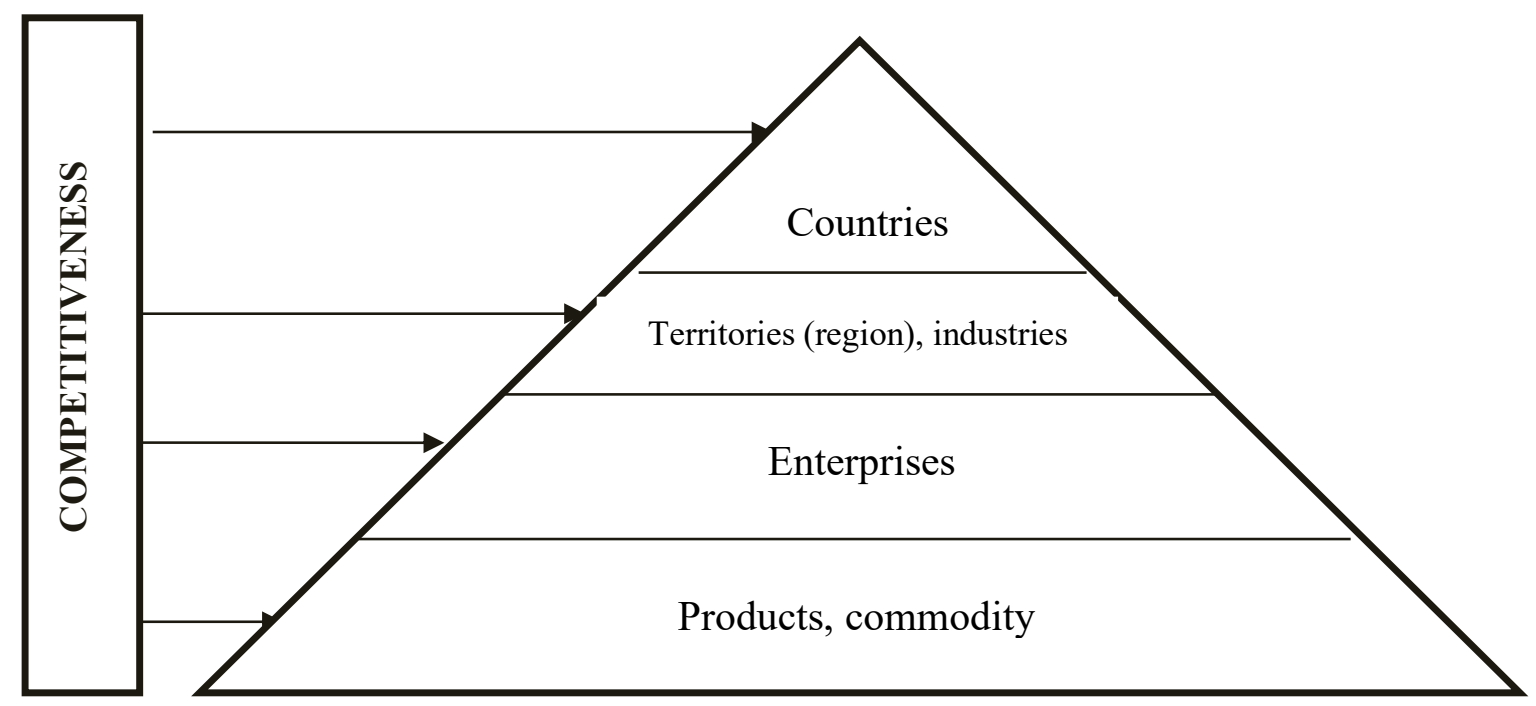

Figure 1. Multilevel model of competitiveness

Source: compiled by the author on the basis of Ivanov (2010), Oleksenko (2007), Osovska (2009)

Competitiveness of a product (commodity) is a comparative characteristic that determines the difference between the analyzed product and the competitors' analogues and contains a comprehensive assessment of the totality of its properties relative to the identified market requirements or qualities of another product.

It is customary to understand competitiveness of an enterprise as its totality of indices of the performance of the enterprise, that determine its success in a particular market over a certain period of time relative to the totality of indices of the enterprises-competitors.

The broader concept of an industry competitiveness is characterized by the totality of the indices of performance of the industries and performance of the production structures, that determine their stable development and success in competition in the domestic and foreign markets. It is assessed by the level of competitiveness of its individual enterprises and their products.

Competitiveness of a country is understood as the ability of national manufacturers to sell their products, the ability to increase or at least keep on parts of the markets sufficient for the expansion and improvement of production, improvement of the living standards, for the support of a 


\section{Oksana Senyshyn, Oleksandr Kundytskyj, Marta Zlydnyk \\ Concept of Product Competitiveness Management System and Principal Scientific Approaches to its \\ Understanding}

strong and successful state (Ivanov, 2010). M. Porter defines a country's competitiveness as the place it occupies in the world economy (Porter, 1993). Thus, the level of competitiveness of a country is ensured by the level of competitiveness of individual enterprises of that country and the country succeeds when the conditions contribute to the implementation of the best strategy by the enterprises of any industry or its segment. Some particularities of the country facilitate or, on the contrary, complicate implementation of a strategy.

The lowest level in the multilevel hierarchical model of competitiveness is competitiveness of a product or commodity, that shows its ability to respond best to the customers' demands compared to similar products presented in the market (Ivanov, 2010).

Thus, we interpret the concept of product competitiveness management that is understood to mean a set of methods, tools, mechanisms aimed to ensure the real and potential ability of food products to dominate over the competitors' products for a long time, constantly improving it, developing key business processes to improve them in accordance with developed strategy and market trends, relying on efficient use of available resources, taking into account the volatile demands of the external environment and the long-term cooperation with partners.

For the detailed analysis of scientific approaches to product competitiveness management we find it appropriate to define the concept of "product competitiveness management system" of the enterprise. We believe that it should be considered as a management system on the following grounds:

- immediate management object (managed system) - production and technological cycle of the formation of quality and competitiveness of agro-food products at all stages of the reproduction cycle;

- management subject (managing system) - work collective of the enterprise, organization present in the market; managing bodies that perform general and specific functions in the product quality and competitiveness management system;

- management process - is an information process; the purpose (task) of management that the management subject faces - elaboration of such management influences, under which the state of the management subject is acceptable from the standpoint of criteria of performance effectiveness of the organization;

- decision-making process for quality and competitiveness management of food products that can be attributed to poorly structured management tasks.

In general terms the product competitiveness management system can be represented as shown in Figure 2.

The managed system is affected by $\left(Y_{1} \ldots m\right)$ inputs, some of which are difficult to assess (changing political, legal, and other conditions that have an effect on operation of an agro-enterprise). The other part of inputs shown in the diagram as $X_{1} \ldots n$ must be studied and assessed by the marketing service of the enterprise, including the one, that having gone through the administrative authorities finds its expression in the form of various regulatory influences $\left(R_{1}, R_{2}\right)$ (see figure 2).

The aim of the product competitiveness management system is to achieve the target levels of quality and production costs of these products so that they would optimally meet requirements of customers, that is, to obtain certain values of $Y$ at any values of $X$. For that reason, the system of product competitiveness management must be constructed of three blocks: production service, quality service and marketing service. 


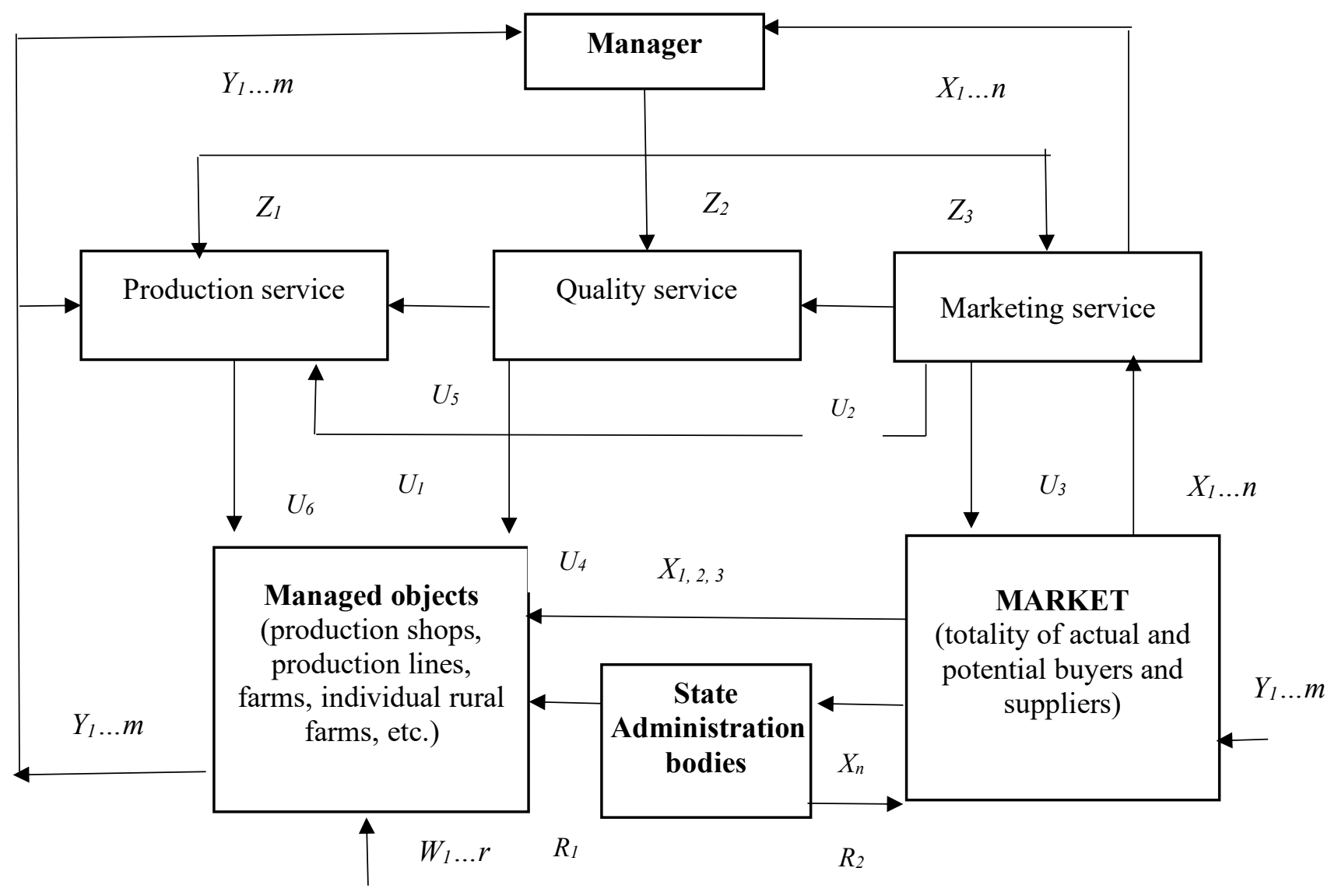

Figure 2. Product competitiveness management system

Source: compiled by the author

Marketing service, being aware of the requirements presented to certain types of food products by actual and potential consumers through the regular marketing studies, communicates this information $\left(X_{1} \ldots n\right)$ to the manager (decision maker) and advises production and quality services on these issues to make adjustments of their managerial influences $\left(U_{1}, U_{2}, U_{5}\right)$. At the same time, the marketing service itself develops a set of measures to influence $\left(U_{3}\right)$ the market (advertising, sales promotion, etc.).

Administrative influences of the agro-enterprise services on the managed object, affect the result, quality and competitiveness of the food products $(Y)$.

The manager's job is to build a quality management system and competitiveness of agri-food products in such a way, that with the available information about the market $(X)$ the agro-enterprise at this moment reaches the level of food product competitiveness $(Y)$ and this means that the management system actualizes dependence $y=P(X, Y)$, with whose aid it must find the necessary administrative influences on the managed object.

Of great importance in the study of theoretical and methodological principles of product competitiveness management is the issue of diversity of approaches to this concept. Fathutdinov and Osovska (2009) examine a range of approaches to competitiveness management: systemic; logical; reproductive-evolutionary; innovative; complex; global; integrative; virtual; standardized; marketing; exclusive; functional; process; structural; situational (variational); normative; optimization; top-down (administrative); behavioral; business. A detailed analysis of scientific sources on the theoreticalmethodological and applied principles of competitiveness management allowed the author to group scientific approaches to it into two groups (Table 1): 


\section{Oksana Senyshyn, Oleksandr Kundytskyj, Marta Zlydnyk \\ Concept of Product Competitiveness Management System and Principal Scientific Approaches to its Understanding}

Table 1. Composite table of principal scientific approaches to the analysis of theoretical-
methodological and application-oriented principles of competitiveness management

\begin{tabular}{|c|c|}
\hline $\begin{array}{l}\text { Types of } \\
\text { approaches }\end{array}$ & Brief analysis of science-based approach \\
\hline \multicolumn{2}{|r|}{ Classical approaches } \\
\hline Process & $\begin{array}{l}\text { Examines general functions of management as interdependent functions. The process of } \\
\text { management is a chain of uninterrupted activities in strategic marketing, planning, } \\
\text { organization of processes, accounting and control, motivation and regulation }\end{array}$ \\
\hline Systemic & $\begin{array}{l}\text { Methodology of the study of objects is imp lemented through the prism of systems. In such } \\
\text { approach the system consists of two components: 1) primary-external environment; 2) } \\
\text { secondary-internal structure }\end{array}$ \\
\hline Synergetic & $\begin{array}{l}\text { Development of systemic approach to complex management systems. According to the } \\
\text { convictions of scientists-economists taking into consideration synergetic regularities permits } \\
\text { to replace the traditional assumptions about management according to which the effect of } \\
\text { managerial influence conclusively and linearly depends on the strength of efforts }\end{array}$ \\
\hline Situational & $\begin{array}{l}\text { Based on the alternativeness of achievement of the same goal at the time of taking or } \\
\text { implementation of the managerial decision, consideration of undetermined circumstances. } \\
\text { This approach focuses on the assumption that the use of some parameters and methods of } \\
\text { management is determined by a specific situation in a specific place and time }\end{array}$ \\
\hline Structural & $\begin{array}{l}\text { Determination of significance, priorities among the factors, methods, principles and other } \\
\text { instruments in their totality for the purpose of establishing rationality of the ratio and } \\
\text { feasibility of the resources }\end{array}$ \\
\hline Functional & $\begin{array}{l}\text { Demand is regarded as a totality of functions that have to be performed to satisfy the demand. } \\
\text { A chain of development of the object: demands-functions-indices of the future object - } \\
\text { changes in the system's structure }\end{array}$ \\
\hline Reflective & $\begin{array}{l}\text { Targeted organization of reflective influences aimed the object of management in order to } \\
\text { improve the competitive standing of the enterprise in the market, particularly, its products }\end{array}$ \\
\hline $\begin{array}{l}\text { Reproducing- } \\
\text { evolutionary }\end{array}$ & $\begin{array}{l}\text { Oriented towards resumption of manufacture of the product to satisfy the demand of a } \\
\text { specific market with lower total expenditures per unit of useful effect. Each new model must } \\
\text { be better than the replaced model }\end{array}$ \\
\hline Top-down & $\begin{array}{l}\text { Envisages regulation of the functions, rights, obligations, quality standards, expenditures, } \\
\text { duration, elements of the management system in normative acts }\end{array}$ \\
\hline Behavioral & $\begin{array}{l}\text { Focuses on the individual and group behavior. Gives the opportunity to improve efficacy and } \\
\text { resulting quality of the work of personnel, intensify generation of new ideas, it improves } \\
\text { efficacy of the organization's work and creates additional competitive advantages }\end{array}$ \\
\hline Complex & $\begin{array}{l}\text { Obligatory is taking into consideration of technical, environmental, economic, } \\
\text { organizational, social, psychological aspects of management of competitiveness and their } \\
\text { interdependencies }\end{array}$ \\
\hline \multicolumn{2}{|r|}{ Specific approaches } \\
\hline Logical & $\begin{array}{l}\text { The main means are the principles of dialectic and formal logic. Principles of dialectic logic: } \\
\text { principle of objectivity of the object assessment; principle of multifaceted object assessment; } \\
\text { principle of historicism. Methodological principles of formal logic: identity principle; } \\
\text { principle of noncontradiction; principle of excluded middle; principle of sufficient reason }\end{array}$ \\
\hline Marketing & Orientation of the management system towards consumer when solving tasks \\
\hline Innovative & Orientation of the enterprise development system towards stepping up innovation activity \\
\hline Global & $\begin{array}{l}\text { Ensuring competitiveness of the large objects must be a global system and not on the level } \\
\text { of the object's location }\end{array}$ \\
\hline Integrative & $\begin{array}{l}\text { Envisages strengthening of collaboration of management entities, their association, } \\
\text { enhancement of interaction between the management system components }\end{array}$ \\
\hline Normative & Establishment of competitiveness standards \\
\hline Logistical & Optimization and rationalization of economic flows of the enterprise \\
\hline
\end{tabular}




\begin{tabular}{|l|l|}
\hline Exclusive & $\begin{array}{l}\text { Establishment of durable competitive advantages through acquiring know-how and } \\
\text { innovations in various spheres of management: manufacture and technologies, personnel, } \\
\text { marketing finances, etc. }\end{array}$ \\
\hline Virtual & $\begin{array}{l}\text { Formation of virtual organizational structures, processing, use and transfer of information to } \\
\text { satisfy the relevant demands with the possibility of functioning in the local market and } \\
\text { compete on the global scale without direct contacts with clients, virtually crossing the longest } \\
\text { distances }\end{array}$ \\
\hline Standardizing & $\begin{array}{l}\text { Realized by way of choosing the optimal ratio between the standard and individual solutions } \\
\text { when forming the objects and by way of developing and introduction of the system of } \\
\text { standards of the appropriate category }\end{array}$ \\
\hline Optimization & $\begin{array}{l}\text { Transfer from qualitative to quantitative estimates with the aid of operation research methods, } \\
\text { engineering calculations, statistical methods, expert assessments. Realized through the } \\
\text { establishment of interdependence between technical-organizational and economic indices, } \\
\text { study of the mechanisms of action of the law of scale }\end{array}$ \\
\hline $\begin{array}{l}\text { Business } \\
\text { The most complex and complicated because everyone has his own understanding of this } \\
\text { approach depending on the individual traits, upbringing and education. Completeness and } \\
\text { degree of practical application of this approach when elaborating the management decisions } \\
\text { are determined by objective and subjective factors. }\end{array}$ \\
\hline $\begin{array}{l}\text { Based on the } \\
\text { concept } \\
\text { "food safety" }\end{array}$ & $\begin{array}{l}\text { Envisages not only taking into account economic, organizational, innovative and other } \\
\text { competitive advantages of specific commodity or a product, but also formation a system of } \\
\text { quantitative and qualitative indices whose observance will ensure both, economic and food } \\
\text { safety }\end{array}$ \\
\hline
\end{tabular}

Source: compiled by the author on the basis of Balabanova (2008), Fatkhudinov (2001), Makarova (2010), Mullakhmetov (2011), Petrovych (2012), Senyshyn (2014), Tarnavsjka (2010)

1) classical approaches, among them process, systemic, synergetic, situational, structural, functional, reproductive-evolutionary, top-down, behavioral, complex, etc.;

2) specific approaches - logical, marketing, innovative, global, integrative, normative, logistical, exclusive, virtual, optimization- business, approach based on the concept of "food safety", etc.

Let us present a detailed description of some of the above said approaches.

Process approach to competitiveness management, that to some extent is a part of the systemic approach, is understood to mean orientation of an enterprise towards business processes, and the management systems are directed at managing both, each business process separately and all business processes. According to the well-known scientists-researchers in the sphere of the enterprise and its products competitiveness expediency of using the process approach to the enterprise competitiveness management boils down to the following (Lepejko, 2012; Kotlyk, 2012):

- firstly, all enterprise subsystems can be shown on the level of individual processes;

- secondly, the consumer value of the products manufactured by the enterprise is created precisely in the processes where basically competitiveness of both, individual product and the enterprise in general is formed (created);

- thirdly, these are precisely the processes of transformation of input resources into the finished products that are the basis of the enterprise competitiveness;

- fourthly, analysis of individual production processes allows to identify and analyze the problems of ensuring competitiveness of the product and of the enterprise in general.

The process of product competitiveness management proper in accordance with the process approach is a chain of uninterrupted interdependent activities in strategic marketing, planning, organization of processes, accounting and control, motivation, regulation. Coordination of the works is central and begins with the strategic marketing management (Fatkhutdinov, 2009; Osovsjka, 2009). It should be noted that the process concept in the study of general management considers marketing 


\section{Oksana Senyshyn, Oleksandr Kundytskyj, Marta Zlydnyk \\ Concept of Product Competitiveness Management System and Principal Scientific Approaches to its \\ Understanding}

as a special, not a general function. Thus, particularities of this approach to product competitiveness management become evident.

Through the prism of the process approach strategic marketing is a complex of works predicting competitiveness standards based on strategic market segmentation, prediction of product values aiming at maintaining or achieving competitive advantages of the enterprise and stable deriving of a sufficient profit. Product competitiveness standards materialize in the sphere of production and are realized through deriving a profit at the stage of tactical marketing as a complex of works in the tactical market segmentation, advertising and sales promotion (Fatkhutdinov, 2009; Osovsjka, 2009).

Systemic approach is typical of numerous management and economic phenomena.

Here an organization is regarded as an open system, that is a totality of such interdependent elements as people, structures, tasks and technologies oriented towards achievement of the organization's goals in a changing external environment (Mullakhmetov, 2011). Accordingly, systematic approach to competitiveness management involves complex management of competitiveness factors in order to achieve a synergetic effect.

Synergetic approach should be considered as the development of the systemic approach to complex management systems (Mullakhmetov, 2011). According to scientists-economists, taking into account synergetic regularities allows to substitute the traditional ideas about management, according to which the effect of administrative influence managerial influence conclusively and linearly depends on the strength of efforts. From the standpoint of administrative activity, the most important and useful can be the following regularities of their development: it is expedient to carry on development of complex enterprises on the basis of identification of their own trends of development and using the latter for the achievement of the set goals; in the periods of instability, even minor administrative influences can produce a considerable effect on the development of the entire enterprise.

Situational approach emerged as the answer to the question: what of the variables of the organization or its environment is important or especially important? (Kredisov, 2001). Under this approach, there is no single, best of all, method to manage competitiveness of an enterprise or its products. The variety of factors both, at the enterprise and in the environment shows to the effect of the «law of the situation». That is, the art of the situational approach to competitiveness management is finding the most important variables in each specific situation and to choose, develop methods whose application would a have an impact on the effectiveness of achieving the goals of the enterprise.

Structural approach to the problems of product competitiveness management means determination of importance, priorities among the factors, methods, principles and other instruments in their totality for the purpose of establishing rationality of the ratio and feasibility of the resources (Lepejko, 2012; Kotlyk, 2012). Structuring gives the opportunity to identify the most important factors for the product competitiveness and its elements and, with the optimal use of such data, to enhance competitiveness of the enterprise.

Implication of the functional approach is that the need for a competitive commodity is seen as a totality of functions that must be performed to satisfy such need. Once the functions have been identified, several alternative objects are created to perform these functions, and the one of them is selected, that requires the minimal total cost of the object's life cycle per unit of its useful effect. This approach is the brainchild functional-cost analysis.

Reflective approach to management of the enterprise competitiveness envisages a targetoriented organization of reflective influences aimed the object of management in order to improve the competitive standing of the enterprise in the market, particularly, its products (Mal'chik, 2010).

Reproducing-evolutionary approach oriented towards resumption of manufacture of the product to satisfy the demand of a specific market with lower total expenditures per unit of useful effect. Each new model must be better than the replaced model (Fatkhutdinov, 2009; Osovsjka, 2009). 
This approach, at the first glance, is quite simple, since in this case the existing manufacturing and technological capabilities of enterprises are used. However, a deeper analysis gives the opportunity to become aware of the complexity and effectiveness of this approach to management.

Theoretical and methodological essence of the top-down approach envisages regulation of the functions, rights, obligations, quality standards, expenditures, duration, elements of the product competitiveness management system through normative acts (orders, resolutions, instructions, standards, prescriptions, plans, programs, regulations, procedures, etc.).

Another approach to product competitiveness management is the behavioral approach, that focuses on the individual and group behavior (Dishe, 2006). In general terms it describes the substance of personnel management in organizations, but it is also fit for product competitiveness management. Once this approach improves efficacy and resulting quality of the work of personnel, intensifies generation of new ideas, it improves efficacy of the organization's work and creates additional competitive advantages.

Complex approach is interpreted as taking simultaneously into consideration various aspects of product competitiveness management: technical, environmental, economic, organizational, social, psychological, demographic, etc. aspects.

Let us now consider specific approaches to product competitiveness management.

Thus, the substance of the logical approach to competitiveness management lies in application of the principles of dialectic logic: principle of objectivity of the object assessment; principle of multifaceted object assessment; principle of historicism, etc. by applying this approach, where feasible, it is possible to use further on an innovative approach. According to the interpretation proposed by Fathutdinov and Osovska (2009), it may be concluded that this approach is not applied to a separate product or an enterprise, but to the innovative orientation of economy of an individual country in general.

Marketing approach involves orientation of the managing subsystem when solving any tasks for external and internal consumers. Marketing management envisages actions that include analysis, planning, implementation and control of measures aimed at formation and stimulation of the demand for goods or services and an increased profit (Gharkavenko, 2006).

Important for the study of the problem of product competitiveness management is also the global approach, typical of the transnational companies, for it is based on consideration of competitive advantages not as an internal element, but as a global (international) phenomenon, whose management must be a supersystem.

Rather popular in the present-day environment is the integrative approach to competitiveness management. This approach is based on strengthening cooperation of the management subjects and focuses on the study and strengthening of their interrelationship (Fatkhutdinov, 2009; Osovsjka, 2009):

- between individual subsystems and components of competitiveness of the enterprise;

- between stages of the product life cycle (strategic marketing, scientific research and development, organizational and technological preparation of production, manufacture, etc.);

- horizontal interrelationship between the management subjects.

Economic substance of the normative approach to competitiveness management lies in the establishment of standards of management in all subsystems of the strategy of raising competitive capacity of both, products and the enterprise in general. This approach envisages establishment of standards for the most important elements of the subsystems: target-oriented, supporting, managed and managing. These standards must meet requirements of complexity, effectiveness, feasibility and viability of application on scale and in time.

The substance of the exclusive approach to competitiveness management lies in acquiring by the enterprise of the exclusive right to use an innovation in any sphere of activity or a competitive advantage. In other words, the content of this approach lies in the creation of durable competitive advantages by way of know-how and innovations acquisition in various spheres of management. 


\section{Oksana Senyshyn, Oleksandr Kundytskyj, Marta Zlydnyk \\ Concept of Product Competitiveness Management System and Principal Scientific Approaches to its \\ Understanding}

Development of modern information technologies, advent of mobile offices and technoparks, the use of the Internet has made it possible to develop such an approach to competitiveness management as the virtual approach. This approach envisages formation of virtual organizational structures, acquisition, processing, use and transfer of information to meet relevant needs with the possibility, to act not only on the local level, but compete on the global scale without direct contacts with clients and partners, virtually covering the longest distances.

The idea of the standardizing approach to product competitiveness management is realized by way of choosing the optimal ratio between the standard and individual solutions when manufacturing products and by way of developing and introduction of the system of standards of the appropriate category.

The study of product competitiveness management requires also the use of the optimization approach as well. It involves transfer from qualitative to quantitative estimates with the aid of operation research methods, engineering calculations, statistical methods, expert assessments, etc. optimization approach is realized through the establishment of dependence between technicalorganizational and economic indices, study of the mechanisms of action of the law of scale and the law of economy of time, the laws of economic interrelationship of the costs in production and consumption spheres, dependence between the quality of the product and costs of its production, etc.

In our opinion business approach is the most complex and complicated approach. Completeness and degree of practical application of business approach when approving the management decisions are determined by objective and subjective factors. Since the business approach to management decisions is applied only by managers-executives, the completeness and depth of its application (observance) will be determined by the external environment and management.

One of the approaches to the assessment of competitiveness of agri-food products is our proposed approach based on the concept of "food safety", that unlike the existing classical and specific approaches involves not only taking into account economic, organizational, innovative and other competitive advantages of a specific product, but also formation of the system of quantitative and qualitative indices, whose observance will ensure both, economic and food safety, since it is a question of competitiveness of food products.

In accordance with the foregoing, production of agri-food products must be made considering the safety factors on the level of the enterprise, the country and the international market. Unfortunately, today Ukraine is not yet sufficiently oriented towards the "secure" food products competitiveness in the sphere of food production. It should be borne in mind that the active economic activity of the enterprise, interaction with the environment, change the situation in the market that, in its turn, lays the enterprise under the obligation to adapt to changes.

\section{Discussion}

Future directions of the study will be to study methodology for the assessment of products competitiveness on whose basis there will be constructed the general framework for determination of the comprehensive index of the level of their competitiveness based on exploring the following methodological techniques:

- method of assessment based on the theory of international division of labor. According to this approach the prerequisite for gaining by an industry or an enterprise the strong competitive positions is presence of comparative advantages or relative advantages that allow to provide relatively lower production costs compared to a competing industry or company. Bearing in mind that competitiveness is a relative category, indices based on relative values (such as the share in the market, export volume, etc.) provide little information on the competitive position of the industry or product in the national economy. More informative are indices based on the comparison of one sector with another - these are the so-called competitiveness indices. Among the indicators most often used 
by foreign scientists, it should be worthwhile to distinguish the Relative Export Advantage Index $(R X A)$, the Relative Import Penetration Index (RMP), the Relative Trade Advantage Index (RTA), the Relative Export Advantage Index (RTA) and the Revealed Comparative Advantage Index (RCA) (Chaudhary, 2016; Granabetter, 2016). Thus, considerable attention is focused on the studies of the complex methodology of competitiveness in the academic articles Chaudhary, Granabetter calculation of the index of the revealed comparative advantage of RCA. Analysis of such index examines the state of competition of a separate sector, in comparison with other sectors of the country's economy, with the volume of exports and imports put in the indicator. In the opinion of these scientists, it is customary to use the RCA index in the international economy as well for calculation of the export potential of the industry or sector

In his scientific publications, dealing with the indices of revealed comparative advantage as the new tool for the achievement of competitiveness of agricultural products, Jagdambe (2019) speaks about application of precisely the index of revealed comparative advantage (RCA) that was used at the four-digit level of harmonized system (HS) of classification for a certain period.

Thus, scientific works of Andhale, Kannan (2015) also deal with the index analysis, namely, with revealed comparative advantage in 5the manufacture of agro-processed products. It has been estimated by the authors that India's comparative advantage of agro-processed products falls in line with the rest of the world. The scientists have followed the scheme of commodity aggregation adopted in the World Integrated Trade Solutions (WITS) for the purpose of analysis. Accordingly, agroprocessed products were grouped into the three categories, namely, processed animal, vegetable and food products. The four variants of RCA indices were used to get the products having a comparative advantage to exports.

The noteworthy works of such scientists as Cicerone, McCan, Venhorst (2020) show the need to use such index as the index of the Product Space Position (PSP) that is used to estimate competitiveness of the product in the regional markets. The PSP index is found to outperform other indices. Comparison throws light on the fundamental aspects of network-cognitive-distance-trade arguments. A better positioning in the export-network product space is indeed associated with better local economic outcomes.

German scientist Oelgemöller (2013) in his scientific work "Revealed comparative advantages in Greece, Ireland, Portugal and Spain" speaks about the need to use the revealed comparative advantage index (RCA) precisely for such countries as Greece, Ireland, Portugal and Spain, for these are the countries that have suffered from the economic downfall in the course of the financial crisis and struggled with the crises and recession of the state debt. This is why foreign trade may seem a logical method to restore economic strength of the above said countries of the world. The author finds it expedient to use the revealed comparative advantage index (RCA) for determination of the comparative advantages of the products that have to be manufactured by the countries to achieve an economic growth. The RCA index provides the opportunity to specify the competitive branches of industry in which foreign investments must be attracted and integrated;

- method of integral assessment that gives the opportunity to get a system assessment of the competitive positions of the manufacturer. The comprehensive approach to the assessment of competitiveness is based on the theoretical-methodological works of the well-known scientistseconomists in the sphere of strategic management (Chaudhary, 2016; Granabetter, 2016; Kolkova, 2018). This comprehensive approach, in their opinion, is based on the methods of integral estimation that provides the opportunity to obtain a systemic assessment of the manufacturer's competitive positions. Such works of the above said scientists lay emphasis specifically on the advantage of the integral method - simplicity of calculations and the possibility of a definitive interpretation of the obtained results;

- methods of determining the competitiveness of the enterprise or products based on taking into consideration the combined action of the determinants of the «national rhombus» and the strategic potential of the enterprise, and the comparison with the standard - the method of taxonomic 


\section{Oksana Senyshyn, Oleksandr Kundytskyj, Marta Zlydnyk \\ Concept of Product Competitiveness Management System and Principal Scientific Approaches to its \\ Understanding}

analysis. For example, Saidani, Yannou, Leroy, Cluzel, Kendall (2019) find it expedient to use taxonomic analysis for aggregation of the circular economy (CE) indicators. This study enriches literature by giving a first need-driven taxonomy of $\mathrm{C}$-indicators, which is experienced in several use cases. It provides a synthesis and clarification of the emerging and much needed research theme of $\mathrm{C}$-indicators and sheds some light on the remaining key challenges like their effective uptake by industry.

Taxonomic analysis is widely applied in conducting a comparative analysis in economics as it permits to expand the opportunities of carrying-out a range of comparisons and measurement of the multi-dimensional objects. Taxonomic analysis methods are based on the multi-dimensional economic objects, that is, such objects that are described by a rather wide range of indices. Conducting this analysis will solve the problem of ordering multidimensionality of such a category such as product competitiveness relative to the standard vector-pattern.

\section{Conclusion}

This study, conducted by the author, has shown that the most effective management of competitiveness of a product or an enterprise in general will be in the general will be in case when it considers the positive aspects of all existing approaches.

In the result this scientific research the authors arrived at the following conclusion:

1. Owing to this research the author presents the author's understanding of the concept "enterprise's product competitiveness management system". In our opinion it is appropriate to consider it as a management system proceeding from the following points: immediate management object (the managed system); management subject (the managed system); management process and the process of approval of the decision on products quality and competitiveness management.

2. Scientific approaches to understanding the concept of product competitiveness management are organized into two groups: 1) classical approaches, to which the author attributes the process, system, synergetic, situational, structural, functional, reproductive-evolutionary, etc. approaches; 2) specific approaches - logical, marketing, innovative, global, integration, optimization and the approach based on the concept of "food safety" and other approaches.

3. The author has proved expediency of using classical approaches in combination, for example, of systemic and process approaches, which will provide the opportunity to make a comprehensive assessment of competitiveness of both, the products and the enterprise, its management system both, in general and on the level of competitive advantages, and conduct analysis of the situation within one particular system.

4. The need for introduction of the new author's approach to the entire range of approaches to product competitiveness management has been substantiated and confirmed - the approach based on the concept of «food safety», that, unlike the existing classical and specific approaches, envisages not only taking into account economic, organizational, innovative and other competitive advantages of the specific products, but also formation of a system of quantitative and qualitative indices whose observance will ensure elimination of both, economic and food security risks, as here we speak of product competitiveness, which is the object of the study.

\section{References}

Andhale, A., Kannan, E. (2015). Analysis of India's revealed comparative advantage in agroprocessed products // Indian Journal of Economics \& Business. No. 14(1): 115-130.

Balabanova, L.V. (2008). Managing competitive rationality. - Donecjk: DonNUET. 538 p.

Balabanova, L.V., Sardak, O.V. (2014). Diaghnostyka konkurentospromozhnosti brendu pidpryjemstvarobotodavcja [Diagnosis of the competitiveness of the employer brand of the enterprise] // Ekonomichnyj chasopysXXI. No. 1-2(1): 94-97. http://nbuv.gov.ua/UJRN/ecchado_2014_1-2(1)_25. 
Chaudhary, A. (2016). Revealed Comparative Advantage Index: An Analysis of Export Potential of Indian Textiles Industry in the Post MFA Period // American Journal of Economics. No. 6(6): 344-351. doi:10.5923/j.economics.20160606.05.

Cicerone, G., Mccann, P., Venhorst, V. A. (2020). Promoting regional growth and innovation: relatedness, revealed comparative advantage and the product space // Journal of Economic Geography. Volume 20. Issue 1: 293-316. https://doi.org/10.1093/jeg/lbz001.

Dishe, Dzhill (2006). Customer Relationship Management. - Kiev: Izdatel'stvo Alekseya Kapusty. 375 p.

Fatkhudinov, R.A. (2001). Strategic management. - Moskva: Delo. 448 p. $470 \mathrm{p}$.

Fatkhutdinov, R.A., Osovsjka, Gh.V. (2009). Organization competitiveness management. - Kyjiv: Kondor.

Gharkavenko, S.S. (2006). Marketing. - Kyjiv: Libra. 720 p.

Granabetter, D. (2016). Revealed Comparative Advantage Index: An Analysis of Export Trade in the Austrian district of Burgerland// Review of Innovation and Competitiveness: A Journal of Economic and Social Research. No 2(2): 97-114.

Hubenko, V. (2003). Mekhanizm zrostannia konkurentospromozhnosti tovariv APK na svitovomu rynku [The mechanism of increasing the competitiveness of agricultural products in the world market] // Ahroinkom. No. 1-2: 58-62.

Ivanov, Ju.B., Kyzym, M.O., Tyshhenko, O.M., Ivanova, O.Ju., Revenko, O.V., Chechetova-Terashvili, T.M. (2010). Management of enterprise competitiveness. - Kharkiv: INZhEK. 320 p.

Jagdambe, S. (2019). Consistency Test of Revealed Comparative Advantage Index: Evidence from India's Agricultural Export // Foreign Trade Review, No. 54(1): 16-28. https://doi.org/10.1177/0015732518810838.

Kolkova, A. (2018). Indicators of Technical Analysis on the Basis of Moving Averages as Prognostic Methods in the Food Industry // Journal of Competitiveness. No. 10(4): 102119. https://doi.org/10.7441/joc.2018.04.07.

Kotlyk, A.V. (2007). Konceptualjni zasady ta pryncypy upravlinnja konkurentospromozhnistju pidpryjemstva na osnovi systemnogho ta procesnogho pidkhodiv [Conceptual principles and principles of enterprise competitiveness management based on systemic and process approaches] // Visnyk Donbasjkoji derzhavnoji mashynobudivnoji akademiji. No. 2: 10-18.

Kredisov, A.I. (2001). History of management studies. - Kyjiv: Znannja Ukrajiny. 300 p.

Lepejko, T.I., Kotlyk, A.V. (2012). Process approach to enterprise competitiveness management. Kharkiv: Vyd. KhNEU. 316 p.

Mal'chik, M.V. (2010). Reflexive management of the competitiveness of industrial enterprises. - Donetsk. $304 \mathrm{p}$.

Mullakhmetov, Kh.Sh. (2011). Modern approaches and concepts in the practice of enterprise management // Management in Russia and Abroad. No. 6: 76-82.

Oelgemöller, J. (2013). Revealed comparative advantages in Greece, Ireland, Portugal and Spain // Intereconomics / Review of European Economic Policy, No. 48(4): 243-253.

Oleksenko, R.I. (2007). Methodical approaches to the formation of product competitiveness // Ekonomy and State. No 5: 48-50.

Osovsjka, Gh.V., Osovsjkyj, O.A. (1993). Management of Organizations. - Kyjiv: Kondor. 680 p.

Petrovych, J.M., Kryveshko, O.V., Stupak, I.O. (2012). Strategic management of industrial enterprise competitiveness. - Lviv: vyd-vo Ljvivsjkoji politekhniky. 228 p.

Plyuta, V. (1980). Comparative multivariate analysis in economic research: Taxonomy and factor analysis methods. - Moskva: Statistika. 174 p.

Porter, M. (1993). International competition. - Moskva: Mezhdunarodnye otnosheniya. 896 p.

Porter, M.E. (1992). Competitive advantage: Creating and sustaining superior performance. - New York: The Free Press. 557 p.

Saidani, M., Yannou, B., Leroy, Y., Cluzel, F., Kendall, A. (2019). A taxonomy of circular economy indicators // Journal of Cleaner Production. No. 207: 542-559. HAL Id: hal-01954800. https ://hal.archivesouvertes.fr/hal-01954800.

Scott, L. and Vollrath, T. L. (1992). Global Competitive Advantage and Overall Bilateral Complementary in Agriculture: Statistical Review. United States Department of Agriculture, Economic Research Service // Statistical Bulletin, No. 850: 111-123. 
Senyshyn, O.S. (2014). Directions of increasing the competitiveness of domestic food products in world markets // Scientific Bulletin of the Kherson State University. No. 6(2): 58-60.

Senyshyn, O., Kundytskyj, O., Klepanchuk, O. (2019). An index analysis for the assessment of the competitiveness of food products in Ukraine // Journal of Competitiveness: scientific periodical journal. Issue 11(2). - Czech Republic: Tomas Bata University in Zlin Centre: 130-143. https://doi.org/10.7441/joc.2019.02.09.

Suchanek, P., Kralova, M. (2018). The Influence of Costumers' Personal Characteristics on their Satisfaction with the Food Industry // Journal of Competitiveness. No. 10(4): 151-170.

Tarnavsjka, N., Makarova, I. (2010). Strategic management of enterprise competitiveness on the basis of innovative priorities // Economic Analysis. No. 5: 344-351.

Tarnavsjka, N.P. (2008). Enterprise competitiveness management: theory, methodology, practice. Ternopil: Ekonomichna dumka. $570 \mathrm{p}$. 